\title{
Optimization of ex vivo expansion of HER2 specific polyfunctional Th1/Th17 cells from HER2 vaccine primed $\mathrm{PBMC}$
}

\author{
Yushe Dang ${ }^{*}$, Lupe Salazar, Jennifer Childs, Doreen Higgins, Mary L Disis \\ From Society for Immunotherapy of Cancer 28th Annual Meeting \\ National Harbor, MD, USA. 8-10 November 2013
}

Adoptive transfer of ex vivo expanded neu specific polyfunctional T-cells secreting TNF-alpha $(\alpha)$, IFNgamma $(\gamma)$, and IL-17 (Th1/Th17) cells into tumor bearing mice can result in complete resolution of disease as compared to the use of neu specific Th1 (Lai et al 2009). Murine antigen specific Th1/Th17 cells could be readily expanded with IL-2 and IL-21 in culture, however, the use of these cytokines resulted in successful expansion of human tumor antigen specific T-cells in only a minority of patients. We sought to identify ex vivo culture conditions that would be suitable for the clinical expansion of polyfunctional HER2 specific Th1/Th17 for therapeutic infusion. PBMC, derived from the aphaeresis of patients previously immunized with a HER2 vaccine, were stimulated with HER2 peptides in the presence of different cytokines to polarize Th17 cells, and then cultured with different $\mathrm{T}$-cell growth factors on Day4/8, and subsequently expanded with CD3/CD28 beads on Day 12 and IL-2 for 12 days. We found that IL-1beta ( $\beta$ )/IL-6 generated higher number of IL-17 secreting CD4 cells before CD3/CD28 activation. Other cytokine combinations, including IL-1 $\beta /$ IL-6/IL-21, IL-1 $\beta /$ IL-6/anti-TGF $\beta$ antibody, and IL-21 alone, failed to further increase IL-17 cells. A low dose of IL-2 alone added in the culture on Day $4 / 8$, following HER2 peptide and IL- $1 \beta / \mathrm{IL}-6$, generated a higher number of antigen specific IL-17 secreting cells than the combinations of IL-2/IL-7 and IL-2/IL-7/ IL-15. In addition, exposure to IL1- $\beta /$ IL- 6 at the time of antigen stimulation was superior to the cytokines added on Day 4/8. Flow cytometric studies of the T-cells generated showed the generation of a Th1/Th17 phenotype, including dual secreting IL-17 and TNF- $\alpha$, IL-17 and

Tumor Vaccine Group, Center for Translational Medicine in Women's Health, University of Washington, Seattle, WA, USA
IFN- $\gamma$, and triple secreting IL-17, IFN- $\gamma$ and TNF- $\alpha$. These data demonstrate a streamlined methodology, easily adaptable to the clinic, for the generation of tumor specific polyfunctional T-cells for therapeutic infusion.

Published: 7 November 2013

doi:10.1186/2051-1426-1-S1-P5

Cite this article as: Dang et al:: Optimization of ex vivo expansion of HER2 specific polyfunctional Th1/Th17 cells from HER2 vaccine primed PBMC. Journal for ImmunoTherapy of Cancer 2013 1(Suppl 1):P5.
Submit your next manuscript to BioMed Central and take full advantage of:

- Convenient online submission

- Thorough peer review

- No space constraints or color figure charges

- Immediate publication on acceptance

- Inclusion in PubMed, CAS, Scopus and Google Scholar

- Research which is freely available for redistribution
() Bïomed Central 